\title{
Magnetic Field Influence on The Properties of Water Treated by Reverse Osmosis
}

\author{
Mahdi O. Karkush \\ Civil Engineering Department \\ University of Baghdad \\ Baghdad, Iraq \\ mahdi_karkush@coeng.uobaghdad.edu.iq
}

\author{
Mahmoud D. Ahmed \\ Civil Engineering Department \\ University of Baghdad \\ Baghdad, Iraq \\ mahmoud_baghdad@yahoo.com
}

\author{
Salem M. A. Al-Ani \\ Civil Engineering Department \\ University of Baghdad \\ Baghdad, Iraq \\ salimalani39@yahoo.com
}

\begin{abstract}
The current study is focused on reviewing the rapid growing of magnetic water use in different science fields and in measuring the influence of several intensities of magnetization on the chemical and electrical properties of tap water treated by reverse osmosis. This work includes water circulation for $24 \mathrm{~h}$ in magnetic fields of intensities $500,1000,1500$, and $2000 \mathrm{G}$. The magnetization of water increases some ions in the water such as $\mathrm{Mg}, \mathrm{K}, \mathrm{Na}, \mathrm{Cl}$, and $\mathrm{SiO}_{2}$ and decreases $\mathrm{Ca}$ and $\mathrm{SO}_{3}$. The main application of magnetic water is the improvement of the geotechnical properties of soft and swelling soil through precipitation of calcite in pores which increases the bond between soil particles and the strength of the soil.
\end{abstract}

Keywords-magnetic field; water; cheimical properties; electric properties; reverse osmosis

\section{INTRODUCTION}

Water is a polar molecule in a V-shaped order of dipoles. Magnetic water is defined as raw or treated water passed through magnetic field of various intensities and circulation periods. Water properties include magnetic sensitivity and when subjected to a magnetic field, these properties change. The changes could be of negative or positive impact according to the use. Water meniscus is not homogeneous and depends on the applied pressure and temperature. Magnetization can affect the two forces that control the water structure, chemical hydrogen bond and Van der Waal's forces, where magnetization can break down its structure, reduce the linkage angle and increase solubility [1, 2]. It is found that the magnetic field changes the size of the water clusters which in turn changes the physical properties of water $[3,4]$. Increase in the intensity of magnetic field causes decrease of the surface tension of tested water samples, which reduces the capillary rise of water [5]. The magnetic field application in wastewater has improved its physical and biological property performance in terms of solid-liquid separation through aggregation of colloidal particles and improvement of bacterial activity [6]. The compression strength of concrete produced using magnetic water is increased by $10 \%-23 \%$ compared to the concrete mixture prepared with plain tap water [7]. The circulation of raw salt water in magnetic field of $2000 \mathrm{G}$ intensity increased the $\mathrm{K}, \mathrm{Mg}, \mathrm{Na}$, and $\mathrm{Al}$ cations and decreased anions $(\mathrm{Cl}$ and $\mathrm{SO}_{3}$ ). The results of the treatment of irrigation water by magnetic field showed beneficial effects on the germination of seeds, plant growth and development, and crop yield [8]. Authors in [9] investigated the effects of magnetization on the ability of magnetite $\left(\mathrm{Fe}_{3} \mathrm{O}_{4}\right)$ nanoparticles, synthesized by chemical co-precipitation, in removing metal ions from water. The nanoparticles of magnetite are promising potential adsorbents and exhibit remarkable reusability for removal of metal ions from water and wastewater. The effect of magnetic field dependent viscosity on free convection heat transfer of a nanofluid in an enclosure considering Brownian motion had been studied in [10], where the bottom wall had constant heating flux. The results showed that the Nusselt number is an ascending function of the Rayleigh number and the nanoparticle volume fraction, but it is a descending function of viscosity parameter and Hartmann number.

There was significant decrease in salinity measured in terms of electrical conductivity (EC), $\mathrm{Na}$, and $\mathrm{Cl}$ content, in soil irrigated with saline water treated by magnetization. In contrast, there were created non-significant effects on $\mathrm{Mg}^{2+}$ and $\mathrm{HCO}_{3}^{-}$. The deficiency or high cost of potable water pushed farmers to use saline water for irrigation, but the saline water needed to be treated before use. The test results showed that salt contents in soil increased with increasing depth in the column of soil treated with magnetic water where the salts moved deeper during the treatment process [11]. The top layer of soil is very important in agriculture [12]. The influence of magnetization of water on the rate of calcite precipitation and formation on the membranes of reverse osmosis process had been studied in [13]. Tests were conducted on tap water using a module of spiral wound with reverse osmosis membranes. The results did not show any effect for magnetization on the precipitation and formation of calcite. The present study is focused on reviewing the applications of magnetized water in different science fields, especially in water treatment and improvement of the chemical and geotechnical properties of soil. Also, the influence of magnetic field of several intensities on the chemical and electrical properties of water treated by reverse osmosis and ozone has been studied. This water can be used in improving the geotechnical properties of swelling soils.

\section{MAGNETIC WATER APPLICATIONS}

The magnetized water has many applications in different science fields and in industry, especially in green technology. 
The circulation of water in magnetic field can change some of its properties. These changes may be useful in industries associated with water properties like $\mathrm{pH}$, surface tension, electrical resistivity, viscosity, and calcite formation inhibition. Magnetized water has many applications in green technology, e.g. in the remediation of contaminated soil and water. Also, magnetized water can be used as injection fluid in oil recovering areas [14].

\section{A. Water Purification}

The treatment of water can be classified according to its source: domestic, natural, and wastewater. According to the quality of water, a specific plan of action will be adopted for reuse, treatment, or disposal. The treatment of water depends on the type and the specifications of effluents. The available techniques of water purification are adsorption, catalytic processes, biotechnology, membrane treatment, ionizing radiation, and magnetization processes. High gradient magnetic separator (HGMS) is a technique commonly used in the separation of particles [15-18]. The application of a magnetic field across a column of water will produce a magnetic gradient along the column and will attract magnetized particles to the surface and help trap these particles, so the collection of particles depends on the magnetic gradient, particle size, and maybe their shape.

\section{B. Wastewater Treatment}

There are many chemical, physical, and biological techniques used for wastewater treatment. The quantity of wastewater is mainly related to the size of population and the level of development. Rapid industry development and growing population produce different types of wastewater which require different types of technology for reuse or treatment. The magnetic field have been used in treatment of wastewater for several purposes such as the removal of colors, heavy metals, suspended solids and turbidity, organic compounds, and toxic chemicals [19-21]. However, more research is required in this field.

\section{Formation of Calcium Carbonate $\left(\mathrm{CaCO}_{3}\right)$}

The formation of $\mathrm{CaCO}_{3}$ has the attention of many researchers because of its wide range of applications in engineering processes, e.g. as cementing agent, adsorbent material, and brightener filler [22-26]. The sedimentation of $\mathrm{CaCO}_{3}$ causes damages and operational problems such as blocking of pipes, clogging of membranes, and efficiency decay in heaters. Several methods have been used to prevent precipitation of $\mathrm{CaCO}_{3}$ (scaling) such as water decarbonization through electrochemical processes and addition of acid and chemical inhibitors. Keeping in mind that chemical treatment may be harmful to public health, therefore, physical techniques have been developed to avoid the use of chemicals. One of these techniques is the magnetic treatment of hard water [2627]. The precipitation of different types of crystals under the existence of a magnetic field proved that $\mathrm{CaCO}_{3}$ is considered the most thermodynamically stable crystal at standard temperature and pressure and forms thick layers that are difficult to be removed mechanically [28-30]. Improvement and remediation of soil is considered one of the important fields in geotechnical engineering. The application of magnetic field to the water circulated through weak, swelling or contaminated soils may help to build bonding between particles of soil through precipitation of calcite in soil pores. These bonds depend mainly on the quantity of calcite precipitated in the pores and the ability of calcite in absorbing the contaminants from soil.

\section{Synthesis of PHAs from Biomass Sludge}

The application of magnetic field on bacteria cultivations enhanced their growth [31-33], depending on the gradient of magnetic field and the type of existing microorganisms. Many studies investigated the effects of magnetization on the growth of microorganisms, yet the synthesis of polyhydroxyalkanoates (PHAs) under a magnetic field has not been investigated in details. Also, carbon waste such as activated sludge can be used to reduce the cost of processing [34-37]. Using acetate of concentration more than $200 \mathrm{Cmmol} / \mathrm{l}$ can prevent cell growth and PHA formation [38]. Therefore, magnetization treatment can be used to enhance the production of PHA under unfavorable conditions.

\section{E. Magnetic Water Treatment in Agriculture}

The magnetization of water changes its chemical and physical properties and these changes will affect the soil-waterplant-system. The irrigation of soil with magnetic water will increase the available alkalines such as $\mathrm{Na}, \mathrm{K}$, and $\mathrm{Mg}$ significantly. The magnetic susceptibility of nutrients will determine its behavior under the magnetic field. Generally, the molecules in nonmagnetic water are in loose state, but they cluster together due to attraction forces provided by magnetization. These forces may help pollutants, especially the toxic ones, to move inside the water molecule cluster. Also, the large structure of water molecule clusters or toxic molecules can clog the membrane when they pass through a membrane cell [39-41]. The magnetization of water will prevent the toxic agents from entering its structure, therefore the magnetic water is considered as a bio friendly fluid. Using magnetic water in agriculture will help increase crop yield and benefit the health of biomass. Using magnetic water will help conserve fresh water supplies for the expected water crisis [39, 40, 42].

\section{MATERIALS AND METHODS}

Pure water as a dipolar and associative liquid can alter its intermolecular bonds under the application of magnetic field and transform to a metastable state [43]. The magnetic field will affect both physical and chemical processes of crystallization and dissolution of water molecules [44]. There are two main different types of magnetic field effects. The direct field which affects the biochemical reactions and the indirect field which affects the surroundings [45]. In the first type of magnetic field, the concern might be the possible genetic influences on living organisms, but the second type of magnetic field may have secondary effects such as temperature, pressure, or mechanical stirring. In the present study, the water container was made from plastic fiber (acrylic) material. The used water pump has the following properties: $25 \mathrm{~W}$ power, $18 \mathrm{~m}$ head, $1000 \mathrm{~L} / \mathrm{h}$ flow rate, and $\mathrm{AC} 220 \mathrm{~V}, 50 \mathrm{~Hz}$ and the provided magnetic fields were $500,1000,1500$, and $2000 \mathrm{G}$ in a with plastic tube of $12 \mathrm{~mm}$ diameter. All these parts were connected together in a basin of water containing $10 \mathrm{~L}$ of water 
treated by reverse osmosis (RO) as shown in Figure 1. The water magnetization device was supplied from a local factory. Water treated with RO will be the reference for comparison. The procedure of magnetization of water can be easily described by putting $10 \mathrm{~L}$ of the reference water in the plastic box. The box is supplied with a submersible pump and the magnetization equipment is fixed on the top of the box. The submersible pump is connected to the magnetization equipment by the $12 \mathrm{~mm}$ tube. The circulation of water in the magnetic field was continued for 5 days, but the water's most chemical and electrical properties remained approximately constant after $24 \mathrm{~h}$. The practical use of water magnetic treatment is based on certain changes in its physical and chemical properties. Intensification and stabilization of small initial changes in properties can occur with the help of intermediate mechanisms increasing many times these changes.

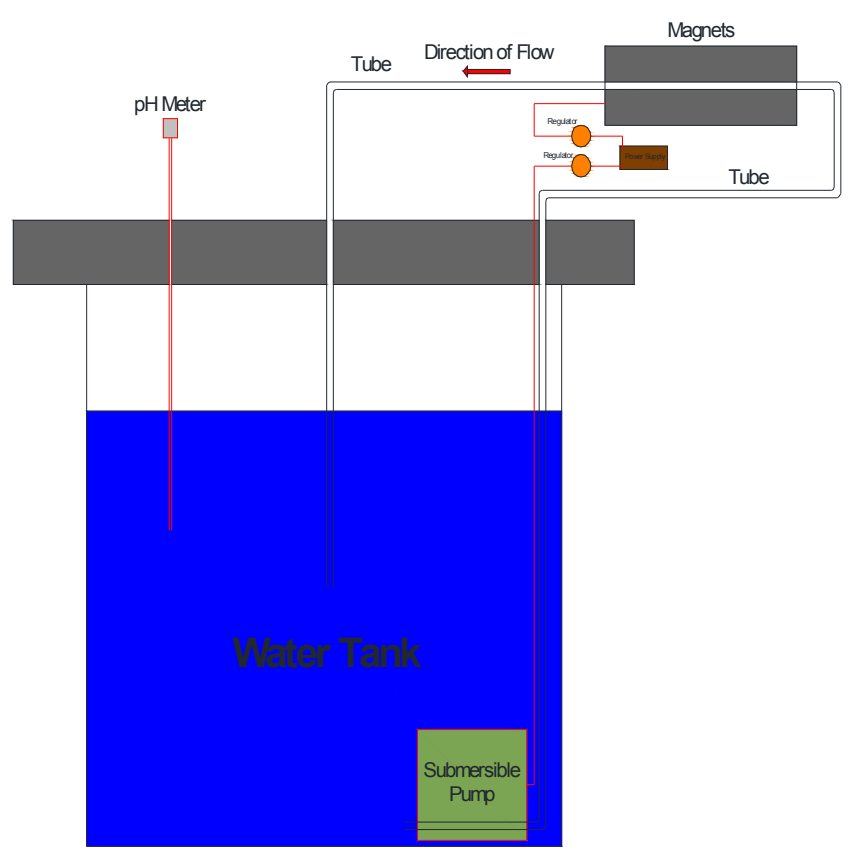

Fig. 1. Schematic diagram of the magnetic system.

TABLE I. WATER ANALYSIS METHODS

\begin{tabular}{|c|c|c|}
\hline Parameter & Symbol & Specification \\
\hline $\mathrm{pH}$ & $\mathrm{pH}$ value & ASTM, D1293 \\
\hline Electrical conductivity & $\mathrm{Ec}$ & ASTM, D1125 \\
\hline Total alkaline & Alkaline & ASTM, D1067 \\
\hline Total dissolved salts & $\mathrm{TDS}$ & ASTM, D5907 \\
\hline Silicon dioxide & $\mathrm{SiO}_{2}$ & ASTM, D859 \\
\hline Chloride content & $\mathrm{Cl}^{-}$ & ASTM, D512 \\
\hline Sulfate & $\mathrm{SO}_{4}$ & ASTM, D516 \\
\hline Magnesium, Calcium & $\mathrm{Mg}, \mathrm{Ca}$, & ASTM, D511 \\
\hline Sodium & $\mathrm{Na}$ & ASTM, D4191 \\
\hline Potassium & $\mathrm{K}$ & ASTM, D4192 \\
\hline
\end{tabular}

In most cases, such intensification is inherent to heterogeneous systems and their phase transitions. For example, the slightest stimulation of crystal formation can cause avalanche irreversible bulk crystallization, with all the process consequences. A slight decrease in the hydration degree of solid particles under certain conditions can lead to their mass coagulation, significant improvement in filtration, etc. The tested chemical and electrical properties of water are listed in Table I.

\section{RESULTS AND DISCUSSION}

Previous studies demonstrated that magnetic water treatment influences the molecular and physicochemical properties of water that alter its quality. The effects of magnetic treatment on irrigation water include increasing the number of crystallization centers and altering the free gas content [33]. The factors affecting the magnetization process are flow rate, circulation time, magnetic field intensity, carbonate water hardness of more than $50 \mathrm{mg} / \mathrm{L}$, and the concentration of hydrogen ions in water at $\mathrm{pH}$ value $>7.2$. To determine the influence of magnetic field intensity on the properties of water, several intensities ranging from $500 \mathrm{G}$ to $2000 \mathrm{G}$ produced by common lab devices were applied to water treated by RO. The circulation of water in the magnetic field continued for 5 days, but almost all properties remained constant after $24 \mathrm{~h}$. Experimental studies have shown that magnetic treatment can increase the number of crystallization and modulates the free gas content of the solution [46]. Magnetic treatment on water plays important role in different procedures influencing the crystallization process such as association, dissociation, and nucleation rates $[29,33,47]$

\section{A. Effects of Magnetization on $\mathrm{pH}$}

Pure water is considered neutral when having a $\mathrm{pH}$ value of 7 at room temperature $\left(25^{\circ} \mathrm{C}\right)$, where the amounts of $\mathrm{H}^{+}$ions and $\mathrm{OH}^{-}$ions are equal. Water becomes more volatile as a result of magnetic processing due to the weakening of the hydrogen bonds between its molecules [48]. The magnetic process can change the $\mathrm{pH}$ of water [49]. Decrease in $\mathrm{pH}$ is caused by the formation of calcite nuclei resulting from the liberation of $\mathrm{H}^{+}$ions.

$$
\begin{aligned}
& \mathrm{CO}_{2}+\mathrm{H}_{2} \mathrm{O} \rightleftharpoons \mathrm{H}_{2} \mathrm{CO}_{3} \\
& \mathrm{H}_{2} \mathrm{CO}_{3}=\mathrm{H}^{+}+\mathrm{HCO}_{3}^{-} \\
& \mathrm{Ca}^{2+}+\mathrm{HCO}_{3}^{-} \rightarrow \mathrm{CaCO}_{3}+\mathrm{H}^{+}
\end{aligned}
$$

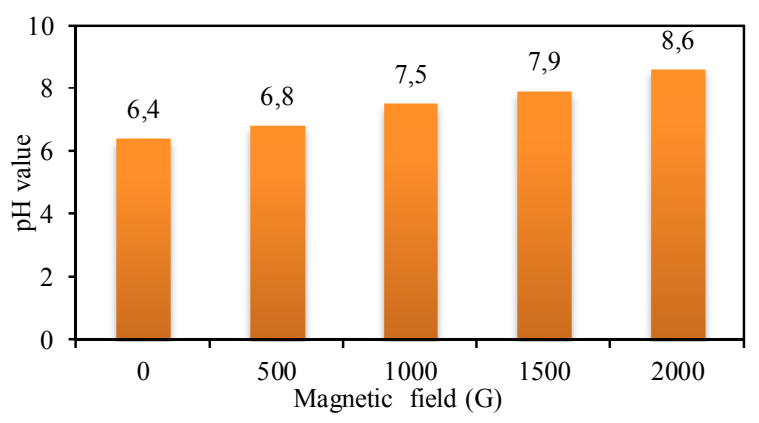

Fig. 2. Concentration of $\mathrm{pH}$ vs magnetic field intensity

Figure 2 shows the variation of $\mathrm{pH}$ under magnetic field of different intensities. When water passed through the magnetic field, the $\mathrm{pH}$ value increased by $6 \%$ to $34.34 \%$ when the magnetic field intensity increased from 500G to $2000 \mathrm{G}$ under 
constant flow rate of $1000 \mathrm{~L} / \mathrm{h}$. For flow rate higher than $2160 \mathrm{~L} / \mathrm{h}$, the $\mathrm{pH}$ value was stable under various magnetic fields [50]. According to the results, the $\mathrm{pH}$ value increases with increasing magnetic field intensity, which means absorption of $\mathrm{H}^{+}$ions and increasing number of $\mathrm{OH}^{-}$ions in the water. These finding were confirmed by previous studies, but with increasing percentage of $0.53 \%$ to $5.6 \%$ [51-53], this difference is mainly due to the quality of the used water and the physicochemical parameters.

\section{B. Effects of Magnetization on Alkalines}

The alkaline metals are basic when dissolved in water with $\mathrm{pH}$ value greater than 7.0. Generally, the water forms more carbonate without magnetization which accelerates the precipitation of calcite. Magnetic field inhibits the precipitation of bicarbonates, and inhibits the formation of calcites, but the magnetization increases the precipitation of $\mathrm{Na}, \mathrm{K}$, and $\mathrm{Mg}$. Mostly, the alkaline metals increase with increasing magnetic field intensity. Also, the magnetic field induces faster proton transfer from hydrogen carbonate to water due to the inversion spin of protons in the diamagnetic field of salts. Figure 3 shows the variation of alkaline concentration with different intensities of magnetic field, where the alkaline concentration increased from $238 \%$ to $450 \%$ when the magnetic field increased from $500 \mathrm{G}$ to $2000 \mathrm{G}$. The test results demonstrated significant increase in the concentration of alkaline minerals with increasing magnetic field intensity. The alkalines may be affected by flow velocity. The intensity of magnetic field did not affect the alkaline content at the highest flow velocity, but had significant effects on the content of alkaline at low flow velocity [54].

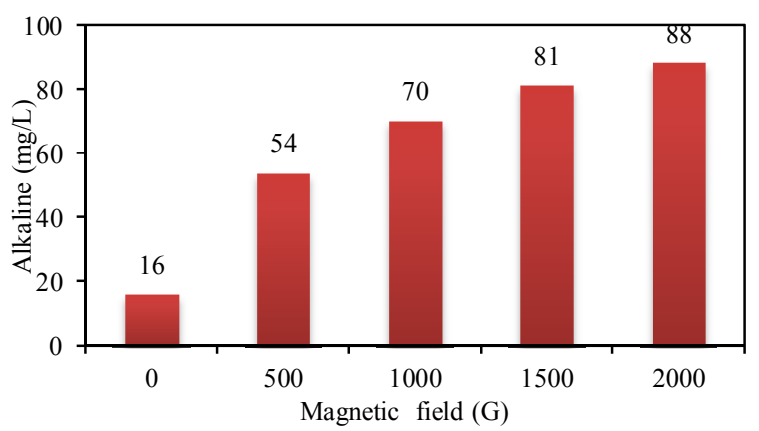

Fig. 3. Concentration of alkalines vs magnetic field intensity

Figure 4 shows the variation of concentration of alkaline minerals: magnesium $(\mathrm{Mg})$, calcium $(\mathrm{Ca})$, sodium $(\mathrm{Na})$, and potassium $(\mathrm{K})$ with different magnetic field intensities. The concentration of $\mathrm{Mg}$ and $\mathrm{K}$ in water increased significantly with increased magnetic field intensity. $\mathrm{Na}$ does not occur freely in nature and is prepared chemically from compounds. $\mathrm{Na}$ salts are highly soluble in water. The concentration of $\mathrm{Na}$ increased significantly when the magnetic field intensity increased. The $\mathrm{pH}$ value increases with increasing magnetic field intensity and the concentration of $\mathrm{Ca}$ ions decreased. In other words, the high precipitation of $\mathrm{CaCO}_{3}$ makes a significant drop in the calcium content. The magnetic field inhibits the growth of crystal particles [54]. The concentration of $\mathrm{Ca}$ decreases with increasing magnetic field intensity.

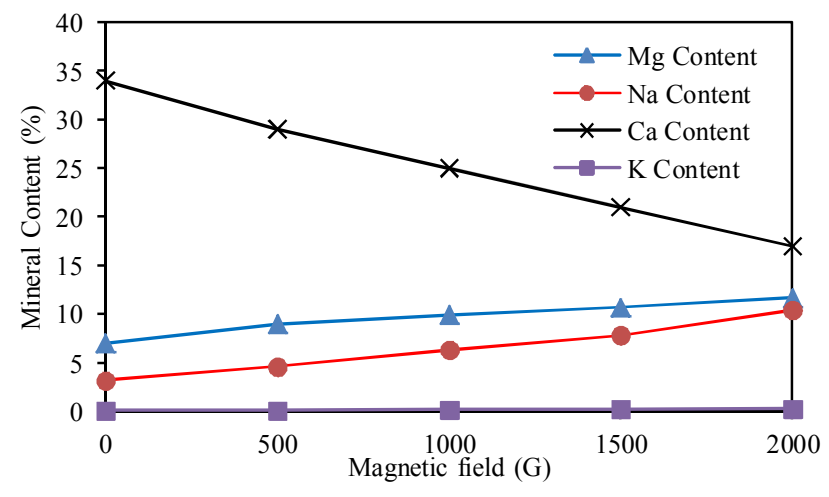

Fig. 4. Concentration of $\mathrm{Mg}, \mathrm{Na}, \mathrm{Ca}$, and $\mathrm{K}$ vs magnetic field intensity

\section{Effects of Magnetization on Chloride}

Chloride $\left(\mathrm{Cl}^{-}\right)$is an anion formed when the $\mathrm{Cl}$ element gains an electron or when a compound such as hydrogen chloride is dissolved in water or other polar solvents. Chloride salts are very soluble in water. Figure 5 shows the variation of $\mathrm{Cl}^{-}$concentration with different magnetic field intensities. The concentration of $\mathrm{Cl}^{-}$increased by $20,45,75,100 \%$ for magnetic field of 500,1000, 1500, and 2000G intensity respectively

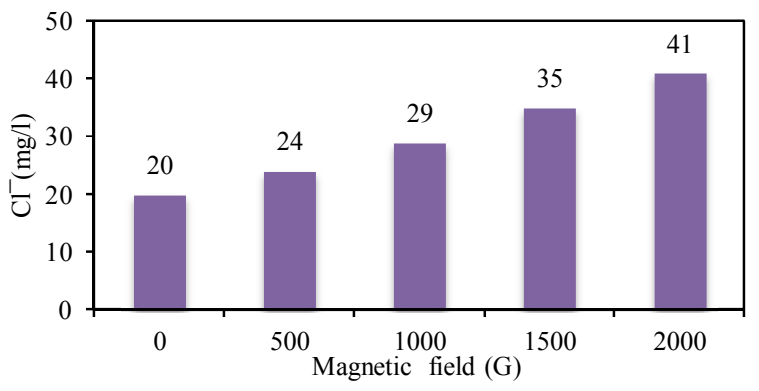

Fig. 5. Concentration of $\mathrm{Cl}^{-}$vs magnetic field intensity

\section{Effects of Magnetization on Silicon Dioxide}

Silicon dioxide $\left(\mathrm{SiO}_{2}\right)$ is a chemical compound extensively found in quartz, sand, and in living organisms. This compound is not very reactive because the polarity of its molecule is zero. Silica is a major compound of sandy soils having many uses in chemical, electronic and pharmaceutical industries.

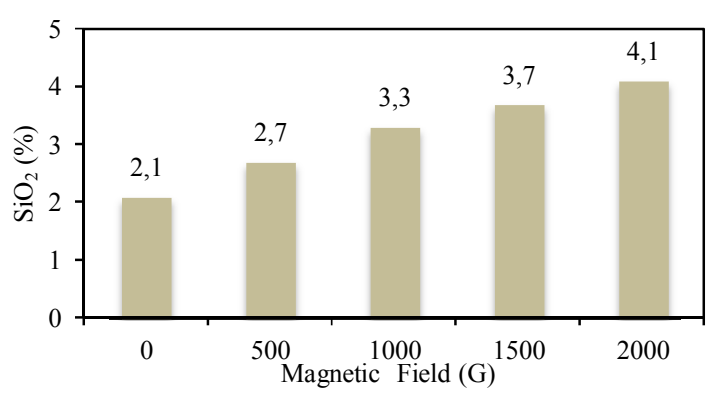

Fig. 6. Concentration of $\mathrm{SiO}_{2}$ vs magnetic field intensity 
Figure 6 shows the variation of $\mathrm{SiO}_{2}$ concentration with different intensities of magnetic field, where $\mathrm{SiO}_{2}$ concentration increased by $28,57,76$, and $95 \%$ when the reference water passed through magnetic field of of 500, 1000, 15000 , and $2000 \mathrm{G}$ intensity respectively.

\section{E. Effects of Magnetization on Electrical Conductivity (EC)}

$\mathrm{EC}$ is the reciprocal of electrical resistivity. It represents the material's ability to conduct electric current. Figure 7 shows the change in EC for different magnetic field intensities at a flow rate of $1000 \mathrm{~L} / \mathrm{h}$, where EC increased from 56 to $264 \mu \mathrm{S} / \mathrm{cm}$ with increasing intensity of magnetic field from 0 to 2000G. The flow rate does not have a significant effect on EC [54]. The EC depends on the ion content. It is observed that decreasing the content of $\mathrm{Ca}$ with increasing intensity of magnetic field causes increase in the EC [54].

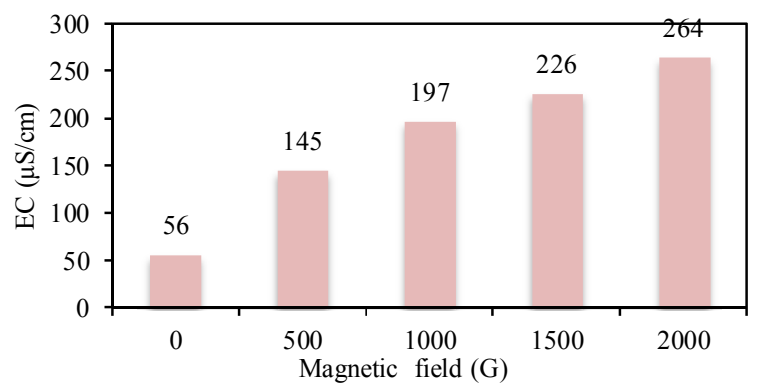

Fig. 7. EC vs magnetic field intensity

\section{F. Effects of Magnetization on Total Dissolve Solids (TDS)}

TDS is a measure of the dissolved inorganic and organic substances present in a liquid in molecular, ionized or microgranular suspended form. Specific types of TDS mainly include calcium, magnesium, potassium, sodium, bicarbonates, chlorides, iron, lead and sulfates. The common sources of dissolved solids in water come from weathering of rocks and erosion of earth's surface. Many minerals are soluble in water, so high contents will be accumulated over time through the constantly reoccurring process of precipitation and evaporation. Groundwater usually has higher contents of TDS than surface water, due to longer duration of contact with the underlying rocks and sediments. Figure 8 shows the variation of TDS content with different magnetic field intensities. We can see that the TDS content in magnetized water increases with increasing magnetic field intensity.

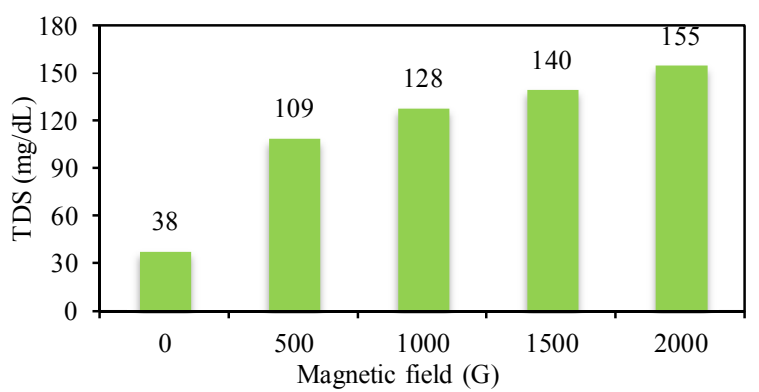

Fig. 8. Concentration of TDS vs magnetic field intensity

\section{G. Effects of Magnetization on Sulfate}

Sulfate $\left(\mathrm{SO}_{4}\right)$ is a polyatomic anion found in water. The sulfate compounds occur from the oxidation of sulfite ores, the presence of shales, and industrial wastewater. Sulfate is considered one of the most common dissolved salts in rainwater. Figure 9 shows the variation of $\mathrm{SO}_{4}$ concentration with different magnetic field intensities, where the circulation of water in a magnetic field causes decreasing in the $\mathrm{SO}_{4}$ content with increasing magnetic field intensity.

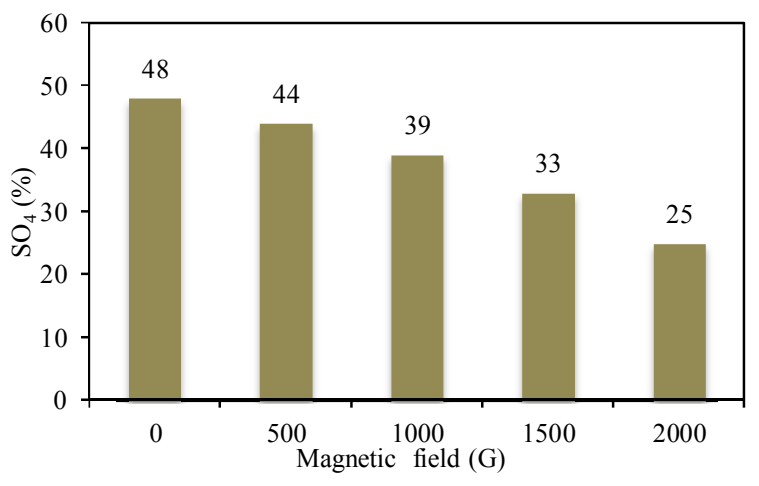

Fig. 9. Concentration of $\mathrm{SO}_{4}$ vs magnetic field intensity

\section{CONCLUSION}

The results of the present study showed that the circulation of water in a magnetic field increases the $\mathrm{pH}$ which indicates increasing water alkalinity. The nucleation of alkaline content increased from $16 \mathrm{mg} / \mathrm{L}$ for reference water to $88 \mathrm{mg} / \mathrm{L}$ for water treated with magnetic field of $2000 \mathrm{G}$ intensity. Also, the magnetic treatment reduces the nucleation of calcium mineral and sulfate content. The results from this research are focused on the influences of magnetic field of varying intensity on the chemical and electrical properties of water treated by reverse osmosis. The experiments changed the content of ions in water as follows:

- After the use of magnetic treatment, $\mathrm{pH}, \mathrm{EC}$ and TDS increased with increased magnetic field intensity.

- Some positive and negative ions such as $\mathrm{Mg}, \mathrm{K}, \mathrm{Na}, \mathrm{Cl}$, Alkaline, and $\mathrm{SiO}_{2}$ increased.

- Some positive and negative ions such as $\mathrm{Ca}$ and $\mathrm{SO}_{4}$ decreased.

- The strength of soil could be improved by this method without using chemical additives to the soil through calcite precipitation. The amounts of sulfate in magnetic field decreased, which is useful to protect concrete from erosion, but the magnetization causes increase in the content of chloride which attacks the reinforcement steel of foundation and causes corrosion.

\section{REFERENCES}

[1] Y. Wang, H. Wei, Z. Li, "Effect of magnetic field on the physical properties of water", Results in Physics, Vol. 8, pp. 262-267, 2018

[2] D. R. Ambashtaa, M. Sillanpaa, "Water purification using magnetic assistance: A review", Journal of Hazardous Materials, Vol. 180, No. 13 , pp. $38-49,2010$ 
[3] M. Iwasaka, S. Ueno, "Structure of water molecules under $14 \mathrm{~T}$ magnetic field", Journal of Applied Physics, Vol. 83, No. 11, pp. 64596461, 1998

[4] S. H. Lee, M. Takeda, K Nishigaki, "Gas-Liquid Interface Deformation of Flowing Water in Gradient Magnetic Field Influence of Flow Velocity and $\mathrm{NaCl}$ Concentration", Japanese Journal of Applied Physics, Vol. 42, No. 4, pp. 1828-1833, 2003

[5] Y. I. Cho, S. H. Lee, "Reduction of the surface tension of water due to physical water treatment for fouling control in heat exchangers", International Communications in Heat and Mass Transfer, Vol. 32, No. $1-2$, pp. 1-9, 2005

[6] N. S. Zaidi, J. Sohaili, K. Muda, M. Sillanpaa, "Magnetic field application and its potential in water and wastewater treatment systems", Separation \& Purification Reviews, Vol. 43, No. 3, pp. 206-240, 2014

[7] B. S. K. Reddy, V. G. Ghorpade, H. S. Rao, "Influence of magnetic water on strength properties of concrete", Indian Journal of Science and Technology, Vol. 7, No. 1, pp. 14-18, 2014

[8] H. Al Najm, Effect of Irrigation Water Salinity and Magnetization and Moisture Depletion in Some Physical Properties of Soil Growth and Yield of Potatoes, PhD Thesis, University Of Anbar, 2014

[9] S. Rajput, C. U. Pittman Jr., D. Mohan, "Magnetic magnetite $\left(\mathrm{Fe}_{3} \mathrm{O}_{4}\right)$ nanoparticle synthesis and applications for lead $\left(\mathrm{Pb}^{2+}\right)$ and chromium $\left(\mathrm{Cr}^{6+}\right)$ removal from water", Journal of Colloid and Interface Science, Vol. 468, pp. 334-346, 2016

[10] M. Sheikholeslami, M. M. Rashidi, T. Hayat, D. D. Ganji, "Free convection of magnetic nanofluid considering MFD viscosity effect", Journal of Molecular Liquids, Vol. 218, pp. 393-399, 2016

[11] M. Hachicha, B. Kahlaoui, N. Khamassi, E. Misle, O. Jouzdan, "Effect of electromagnetic treatment of saline water on soil and crops", Journal of the Saudi Society of Agricultural Sciences, Vol. 17, No. 2, pp. 154162,2018

[12] V. Zlotopolsk, "The impact of magnetic water treatment on salt distribution in a large unsaturated soil column", International Soil and Water Conservation Research, Vol. 5, No. 4, pp. 253-257, 2017

[13] A. Andrianov, E. Orlov, "The Assessment of Magnetic Water Treatment on Formation Calcium Scale on Reverse Osmosis Membranes", MATEC Web of Conferences, Vol. 178, No. 2, Article ID 09001, 2018

[14] E. Esmaeilnezhad, H. J. Choi, M. Schaffie, M. Gholizadeh, M. Ranjbar, "Characteristics and applications of magnetized water as a green technology", Journal of Cleaner Production, Vol. 161, pp. 908-921, 2017

[15] J. Svoboda, "A realistic description of the process of high-gradient magnetic separation", Minerals Engineering, Vol. 14, No. 11, pp. 14931503, 2001

[16] A. Ditsch, S. Lindenmann, P. E. Laibinis, D. I. C. Wang, T. A. Hatton, "High-gradient magnetic separation of magnetic nanoclusters", Industrial \& Engineering Chemistry Research, Vol. 44, No. 17, pp. 6824-6836, 2005

[17] H. Okada, K. Mitsuhashi, T. Ohara, E. R. Whitby, H. Wada, "Computational fluid dynamics simulation of high gradient magnetic separation", Separation Science and Technology, Vol. 40, No. 7, pp. 1567-1584, 2005

[18] M. Sarikaya, T. Abbasov, M. Erdemoglu, "Some aspects of magnetic filtration theory for removal of fine particles from aqueous suspensions", Journal of Dispersion Science and Technology, Vol. 27, No. 2, pp. 193198,2006

[19] L. Wang, J. Li, Y. Wang, L. Zhao, "Preparation of nanocrystalline Fe3xLaxO4 ferrite and their adsorption capability for congo red", Journal of Hazardous Materials, Vol. 196, pp. 342-349, 2011

[20] S. Liu, F. Yang, F. Meng, H. Chen, Z. Gong, "Enhanced anammox consortium activity for nitrogen removal: Impacts of static magnetic field", Journal of Biotechnology, Vol. 138, No. 3-4, pp. 96-102, 2008

[21] A. Tomska, L. Wolny, "Enhancement of biological wastewater treatment by magnetic field exposure", Desalination, Vol. 222, No. 1-3, pp. 368373,2008

[22] B. R. Heywood, S. Rajam, S. Mann, "Oriented crystallization of $\mathrm{CaCO}_{3}$ under compressed monolayers. Part 2.-Morphology, structure and growth of immature crystals", Journal of the Chemical of Society, Faraday Transactions, Vol. 87, No. 5, pp. 735-743, 1991

[23] S. R. Dickinson, K. M. McGrath, "Aqueous precipitation of calcium carbonate modified by hydroxyl-containing compounds", Crystal Growth \& Design, Vol. 4, No. 6, pp. 1411-1418, 2004

[24] J. S. Park, J. H. Yang, D. H. Kim, D. H. Lee, "Degradability of expanded starch/PVA blends prepared using calcium carbonate as the expanding inhibitor", Journal of Applied Polymer Science, Vol. 93, No. 2, pp. 911-919, 2004

[25] C. Y. Tai, C. K. Wu, M. C. Chang, "Effects of magnetic field on the crystallization of $\mathrm{CaCO}_{3}$ using permanent magnets", Chemical Engineering Science, Vol. 63, No. 23, pp. 5606-5612, 2008

[26] F. Alim, M. M. Tlili, M. B. Amor, G. Maurin, C. Gabrielli, "Effect of magnetic water treatment on calcium carbonate precipitation: Influence of the pipe material", Chemical Engineering and Processing: Process Intensification, Vol. 48, No. 8, pp. 1327-1332, 2009

[27] J. Bogatin, N. P. Bondarenko, E. Z. Gak, E. E. Rokhinson, I. P. Ananyev, "Magnetic treatment of irrigation water: Experimental results and application conditions", Environmental Science and Technology, Vol. 33, No. 8, pp. 1280-1285, 1999

[28] J. D. Donaldson, "Magnetic treatment of fluids-preventing scale", Finishing, Vol. 12, No. 1, 1988

[29] Y. Wang, J. Babchin, L. T. Chernyi, R. S. Chow, R. P. Sawatzky, "Rapid onset of calcium carbonate crystallization under the influence of a magnetic field", Water Reseasch, Vol. 31, No. 2, pp. 346-350, 1997

[30] K. Higashitani, K. Okuhara, S. Hatade, "Effects of magnetic fields on stability of non-magnetic ultrafine colloidal particles", Journal of Colloid and Interface Science, Vol. 152, No. 1, pp. 125-131, 1992

[31] J. Jung, B. Sanji, S. Godbole, S. Sofer, "Biodegradation of phenol: A comparative study with and without applying magnetic fields", Journal of Chemical Technology and Biotechnology, Vol. 56, No. 1, pp. 73-76, 1993

[32] T. Utsunomiya, Y. I. Yamane, M. Watanabe, K. Sasaki, "Stimulation of prophyrin production by application of an external magnetic field to a photosynthetic bacterium, rhodobacter sphaeroides", Journal of Bioscience and Bioengineering, Vol. 95, No. 4, pp. 401-404, 2003

[33] Z. Y. Li, S. Y. Guo, L. Li, M. Y. Cai, "Effects of electromagnetic field on the batch cultivation and nutritional composition of Spirulina platensis in an air-lift photobioreactor", Bioresource Technology, Vol. 98, No. 3, pp. 700-705, 2007

[34] H. Salehizadeh, M. C. V. Loosdrecht, "Production of polyhydroxyalkanoates by mixed culture: Recent trends and biotechnological importance", Biotechnology Advances, Vol. 22, No. 3, pp. 261-279, 2004

[35] M. S. Kumar, S. N. Mudliar, M. K. R. Konduri, T. Chakrabarti, "Production of biodegradable plastics from activated sludge generated from a food processing industrial wastewater treatment plant", Bioresource Technology, Vol. 95, No. 3, pp. 327-330, 2004

[36] D. Dionisi, G. Carucci, M. P. Papini, C. Riccardi, M. Majone, F. Carrasco, "Olive oil mill effluents as a feedstock for production of biodegradable polymers", Water Research, Vol. 39, No. 10, pp. 20762084, 2005

[37] S. Bengtsson, A. Werker, M. Christensson, T. Welander, "Production of polyhydroxyalkanoates by activated sludge treating a paper mill wastewater", Bioresource Technology, Vol. 99, No. 3, pp. 509-516, 2008

[38] J. Yu, J. Wang, "Metabolic flux modeling of detoxification of acetic acid by Ralstonia eutropha at slightly alkaline $\mathrm{pH}$ levels", Biotechnology and Bioengineering, Vol. 73, No. 6, pp. 458-464, 2001

[39] L. Pandolfo, R. Colale, G. Paiaro, "Magnetic field and tap water", La Chimica e l'Industria, Vol. 69, No. 11, pp. 88-89, 1987

[40] D. L. Watt, C. Rosenfelder, C. D. Sutton, "The effect of oral irrigation with a magnetic water treatment device on plaque and calculus", Journal of Clinical Periodontology, Vol. 20, No. 5, pp. 314-317, 1993

[41] V. Hogan, S. E. Mason, S. A. Campbell, F. C. Walsh, "The Use of Magnetic Fields in the Prevention of Scaling", UK Corrosion and Eurocorr 94, Bournemouth, UK, October 31-November 3, 1994 
[42] G. Paiaro, L. Pandolfo, "Magnetic treatment of water and scaling deposit”, Annali di Chimica, Vol. 84, No. 5-6, pp. 271-274, 1994

[43] V. K. Golovleva, G. E. Dunaevskii, T. L. Levdikova, Y. S. Sarkisov, Y. I. Tsyganok, "Study of the influence of magnetic fields on the properties of polar liquids", Russian Physics Journal, Vol. 43, No. 12, pp. 10091012,2000

[44] O. Mosin, I. Ignatov, "Magnetohydrodynamic cell for magnetic water treatment", Nanotechnology Research and Practice, Vol. 6, No. 2, pp. $81-92,2015$

[45] J. Nakagawa, N. Hirota, K. Kitazawa, M. Shoda, "Magnetic field enhancement of water vaporization", Journal of Applied Physics, Vol. 86, No. 5, pp. 2923-2925, 1999

[46] M. Yamashita, C. Duffield, W. A. Tiller, "Direct current magnetic field and electromagnetic field effects on the $\mathrm{pH}$ and oxidation-reduction potential equilibration rates of water. 1. Purified water", Langmuir, Vol. 19, No. 17, pp. 6851-6856, 2003

[47] V. Kozic, L. C. Lipus, "Magnetic water treatment for a less tenacious scale", Journal of Chemical Information and Computer Sciences, Vol. 43, No. 6, pp. 1815-1819, 2003

[48] Y. Z. Guo, D. C. Yin, H. L. Cao, J. Y. Shi, C. Zhang, Y. M. Liu, H. H. Huang, Y. Liu, Y. Wang, W. H. Guo, A. R. Qian, P. Shang, "Evaporation rate of water as a function of a magnetic field and field gradient", International Journal of Molecular Sciences, Vol. 13, No. 12 pp. 16916-16928, 2012

[49] J. S. Baker, S. J. Judd, "Magnetic amelioration of scale formation", Water Research, Vol. 30, No. 2, pp. 247-260, 1995

[50] H. B. Amor, A. Elaoud, M. Hozayn, "Does magnetic field change water pH?", Asian Research Journal of Agriculture, Vol. 8, No.1, pp. 1-7, 2018

[51] F. Alimi, Anti-scale Treatment of Hard Water by Magnetic Processes, $\mathrm{PhD}$ Thesis, National Institute of Applied Science and Technology, Tunisia, 2008

[52] A. Elaoud, N. Turki, H. B. Amor, R. Jalel, N. B. Salah, "Influence of the magnetic device on water quality and production of melon", International Journal of Current Engineering \& Technology, Vol. 6, No. 6, pp. 2256-2260, 2016

[53] A. Kotb, A. M. A. E. Aziz, "Scientific investigations on the claims of the magnetic water conditioners", Annals of Faculty Engineering Hunedoara-International Journal of Engineering, Vol. 11, No. 4, pp. $147-157,2013$

[54] L. Jiang, J. Zhang, D. Li, "Effects of permanent magnetic field on calcium carbonate scaling of circulating water", Desalination and Water Treatment, Vol. 53, No. 5, pp. 1275-1285, 2015 